\title{
PPY Gene Product
}

National Cancer Institute

\section{Source}

National Cancer Institute. PPY Gene Product. NCI Thesaurus. Code C129911.

A protein encoded by the PPY gene. 